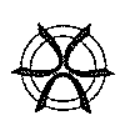

PLANNING MALAYSIA

Journal of the Malaysian Institute of Planners (2004) II, 11-34

\title{
A STUDY TO EVALUATE CHILD-FRIENDLY NEIGHBOURHOODS THROUGH A SET OF CHILD- FRIENDLY INDICATORS
}

\author{
Alias Abdullah \\ Nik Munerahanim Bt. Nik Muhammad \\ Department of Urban and Regional Planning \\ Kulliyyah of Architecture and Environmental Design \\ INTERNATIONAL ISLAMIC UNIVERSITY MALAYSIA
}

\begin{abstract}
Children ${ }^{1}$ constitute the majority of the world's population (UNICEF 1998). They represent the survival of humankind to ensure the continuation of the next generation. Children were born into this world, by nature weak in body, senses and mind. Children are eager to accept education from day to day out of their inner curiosity. Hence, understanding children and creating a good and healthy environment must go hand in hand. In relations, providing a safe environment for children to live, play, run errands, and interacts with others are urban planning priority. However, most of the time, urban designs and housing setting are planned specifically for adults without taking into considerations the needs of the growing number of children. Children must be provided with the most supportive environment possible in order to enhance their capability in coping with their surroundings as well as to increase their capabilities to face challenges in future. For the purpose of these, this paper will have an in-depth study regarding the child-friendly environment, and how the neighbourhoods should be in order to create a safe environment for children. This study has selected three neighbourhoods to be evaluated in terms of the degree of their friendliness towards children. A set of ChildFriendly Indicators is applied as a tool for assessing and evaluating these three neighbourhoods. This paper focuses on diverse aspects pertaining to the child-friendly environment especially on the physical aspects. It will also share some of the recommendations to counter various issues in terms of planning for safe neighbourhoods in the future, as well as the recommendations to improve the developed Child-Friendly Indicators.
\end{abstract}

Keywords: Children, Neighborhood, Child-Friendly Indicators, Child-MesraNet System

\footnotetext{
1 The term "children" is used here in a broad sense of the United Nations' definition, which includes all people under the age of 18 .
} 


\section{INTRODUCTION}

\section{Purpose of Study}

Malaysia is experiencing a tremendous pace of development. The rapid industrialization has increased the rate of urbanization. Despite the fact that children constitute the majority of the world's population, there are limitations to the incorporation of their views and perspectives. Very often, the towns and cities in Malaysia, for instance, are planned and designed for the 'perfect' adult. Urban streets are laid for cars rather than for people, in general, and children, in particular (Badaruddin, 2002). Apart from being limited to voice out their perceptions on their surrounding environment, children are also too often injured and sometimes killed as a result of the hazards in their environment. Unintentional injury continues to be the greatest cause of mortality, morbidity and disability for children. An accident can be an abrupt, unexpected event, which may result in injury or death. Bartlett (2002) acknowledges that accidents represent the highest number of injury-related deaths among children. In relations, approximately one-third of the children died each year between the ages of one to fourteen, caused by accidents, which kill more children than the five leading fatal diseases. Although not the leading cause of death, accidents are the major cause of disability, permanent or temporary, in children over the age of one year. For children under the age of five, accidents are most likely to take place in the home or childcare centres and after the age of five, accidents outside the home, particularly on the roads, are common (Bartlett, 2002). According to the Ministry of Health Malaysia (2000), more children in Malaysia die as a result of motor-vehicular accidents than from any other injury or disease. This implies the importance of road safety while considering issues of child-safety within the neighbourhoods or cities. 


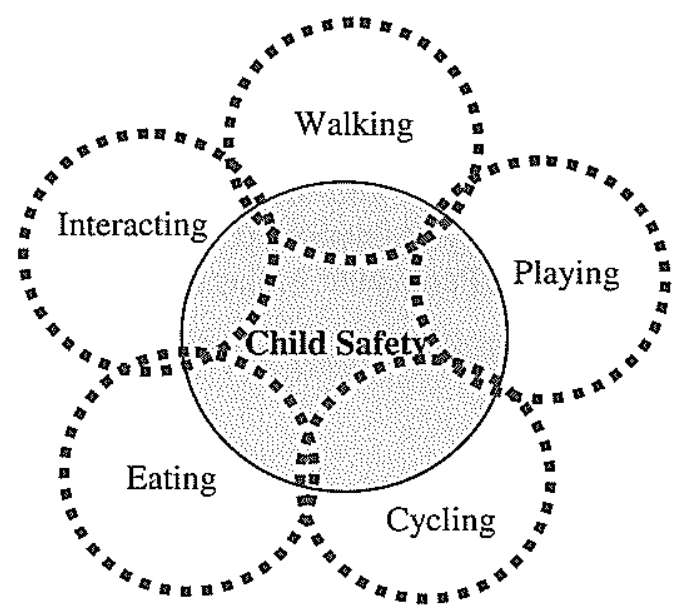

FIGURE 1: Activities of children that need to be safe within the neighbourhoods

Every parent aspires that his or her children will grow up healthy, wellnourished, educated, and protected from harm and ready to face the life ahead. Since we profess love and care for our children, does our planning and urban design produce a child-friendly environment? Children should be able to share in all things cities have to offer, but most often cities are designed as worlds for adults by adults without considering the needs of children. The designated places for children such as playgrounds, schoolyards, and child-care centres, must be appropriately designed according to the standard and needs of the children. Among other things, water fountains, toilets, public telephones are still being built too high for young children to reach. The importance of creating a child-friendly environment has a positive impact in helping the children's development process as well as enhancing the lives of children. Apart from developing their mental growth, the creation of safe environments for children can also help in developing their physical growth.

It is indisputable that the present neighbourhood areas do give consideration to the creation of a child-friendly environment. However, how far does the implementation meet the needs of children? This question will be followed with other questions arguing many other aspects. Among the issues that are often raised with regards to child-friendly environment, in particular the neighbourhood environments are seldom planned with the concern of children in mind. Deficient housing conditions, congestion, pollution, unsuitable locations of children's playground, to name a few, are among the various problems that pose many risks and challenges to the well-being of children. 
Ideally, this study will focus on evaluating and assessing the selected neighbourhoods to establish whether they comply with a child-friendly environment or otherwise. It is important to note that the selected neighbourhoods will be evaluated through a set of Child-Friendly Indicators that has been extracted from the Child-MesraNet System developed by the International Islamic University Malaysia (IIUM) for the Federal Department of Town and Country Planning, Peninsular Malaysia.

\section{SCOPE OF THE STUDY}

i) Selecting neighbourhoods for the study.

ii) Understanding and outlining the Child-Friendly Indicators available in the Child-MesraNet System, selecting appropriate indicators, and incorporating new indicators derived from the literature review. Also providing further improvements to the Child-Friendly Indicators.

iii) Testing the Child-Friendly Indicators on the identified neighbourhoods, whereby the questionnaires are distributed for 50 residents for each neighbourhood.

iv) Assessing and measuring the performance of the neighbourhoods.

v) Proposing recommendations with regard to the neighbourhoods

\section{METHODOLOGY}

The study has been carried out through four stages. Stage one started with the identification of the research problem, which gave the description of what the study was all about. Stage two was the data collection. Two types of data were collected which was the primary and secondary data. The primary data, which was the first hand data, were obtained from the field study in which data were collected directly from the real environment through site observations, questionnaire distributions, and informal interviews with the residents. Different sets of questionnaires were given to both adult and child respondents. The secondary data were obtained through literature review. The literatures were extracted from various sources such as books, established journals and documents, and also from the Internet. Stage three was the process of compiling and editing raw data. The data were analyzed to figure out the result pertaining to the present conditions of the selected neighbourhoods. The data collected, particularly through questionnaires survey and observations were evaluated through a set of Child-Friendly Indicators. Stage four, which was the last stage of the study, emphasizes on the conclusions and recommendations on the 
subject matter. This stage addressed the issues and problems arouse from the development of existing neighbourhoods. The solutions were given in such a way to overcome not only the issues at the study areas but also to improve the development of neighbourhoods in the future.

\section{STUDY AREAS}

For the purpose of getting a general perception of the community on the issue raised, a survey questionnaire was administered to three case study areas, namely, Taman Samudera, Taman Sri Gombak, and Sekyen 3 Petaling Jaya. The selection criteria of these three neighbourhoods were one old established neighbourhood; an intermediate one, and one newly established neighbourhood. Taman Samudera was the newly established neighbourhood, which has been established for less than 10 years, Taman Sri Gombak was the intermediate established neighbourhood as it has been resided for 25 years, and Seksyen 3 Petaling Jaya was the old established neighbourhood, which has been established for 50 years.

\section{CHILD-FRIENDLY INDICATORS}

As have been mentioned earlier, the study areas were evaluated in terms of their friendliness towards the children through a set of Child-Friendly Indicators extracted from the Child-MesraNet System. There were 67 indicators outlined in the Child-MesraNet System. This set of indicators has been formulated in order to measure the minimum quality of children's safety that has to be achieved by each neighbourhood or city in the country. The indicators were grouped into seven sectors namely, Demographic; Utility and Infrastructure; Public Facilities and Recreation; Environment; Sociology and Social Impact, Transportation and Accessibility; and Land Use sector. Due to unavoidable constraints, only 33 out of the 67 indicators have been selected, and three additional indicators derived from the literature review were included in the study.

Generally, for all sectors, the measurement index was varied but the scores were fixed into 3 which are score 1 , score 2 , and score 3 . Score 3 showed the highest while score 1 was the lowest. The higher the score obtained for each indicator, the more child-friendly the area was. On the whole, a neighbourhood, a town or a city was considered as 'child-friendly' if obtained $75.0 \%$ or more of the overall scores. The measurement index, scores, and the calculation of the scores were adapted from the Child-MesraNet System. The 'child-friendly' target, 
which was a minimum of $75.0 \%$ of the scores, has emerged based on the Malaysian standard of measurement, which suits the Malaysian context.

\section{FINDINGS AND DISCUSSION}

\section{Utility and Infrastructure Sector}

The indicators grouped under this sector were related to the cleanliness of the neighbourhoods. This aspect was very important as cleanliness affects the health and well-being of the children in particular. The study has found out that Taman Samudera and Taman Sri Gombak showed a high satisfaction rate in this aspect, whereas Seksyen 3 Petaling Jaya, only showed a moderate rate. In Taman Samudera, the high satisfaction rate towards the cleanliness level of the neighbourhood was due to the effectiveness of the garbage collection system, which was done three times in a week. From the observation it also showed that most of the areas within the neighbourhoods, including school areas and children's playgrounds were well and properly maintained.

From the questionnaires given to the residents in Taman Sri Gombak, it has been found that most of the respondents were satisfied with the provision of garbage disposal facilities and the maintenance and collection system in the residential areas. However, in terms of the garbage facility and the maintenance of this facility in public areas, many of them claimed low satisfaction levels. This was due to the fact that most of the residents, particularly those who resided in Phase 2, were threatened by the heap of rubbish thrown near their residential areas during the night market every Monday. They also claimed that the maintenance of this area was rather low and thus it has encouraged the breeding of certain disease vectors that caused health implications to the children's well-being. In Seksyen 3 Petaling Jaya, the moderate level of residents' satisfaction in this aspect was particularly due to the inadequate provision and low maintenance and collections system of garbage disposal facility in the residential and public areas. Based on the questionnaires, most of them claimed that the inadequacy of garbage bins provided and low maintenance of this facility have worsened the cleanliness level of the neighbourhoods especially in areas that were mostly frequented by children such as schools, playgrounds, and housing areas, thus children's likelihood of playing at these areas become lower. On the other hand, the low level of cleanliness of this neighbourhood could also be due to the attitude of the residents who have the tendencies of throwing rubbish not in the proper places. As acknowledged by Bartlett \& Chawla (2002), the cleanliness of the neighbourhoods may ensure the comfort, good health and safety of the residents, 
particularly the children. In terms of the issue of drains, the site observation showed that the three neighbourhoods faced the same problems of uncovered drains. They were mostly left uncovered and some of them were broken. Informal interviews conducted with the adult residents of these neighbourhoods found out that the majority of them were anxious about their child's safety usually during rainy seasons when the drains were mostly filled with water thus unintentionally causing accidents to their children. Table 1 summarizes the findings of this sector for the three neighbourhoods.

TABLE 1:

Summary of Findings for Utility and Infrastructure Aspect

\begin{tabular}{|c|c|c|c|c|c|c|}
\hline \multirow[t]{2}{*}{ Indicators } & \multicolumn{2}{|c|}{$\begin{array}{l}\text { Taman } \\
\text { Samudera }\end{array}$} & \multicolumn{2}{|c|}{ Taman Sri } & \multicolumn{2}{|c|}{$\begin{array}{l}\text { Seksyen } 3 \\
\text { Petaling Jaya }\end{array}$} \\
\hline & Findings & Score & Findings & Score & Findings & Score \\
\hline $\begin{array}{l}\text { Provision of garbage disposal facility } \\
\text { (garbage bins) in residential area }\end{array}$ & $60.0 \%$ & 3 & $64.0 \%$ & 3 & $36.0 \%$ & 2 \\
\hline $\begin{array}{l}\text { Provision of garbage disposal facility } \\
\text { (garbage bins) in public areas. }\end{array}$ & $60.0 \%$ & 3 & $46.0 \%$ & 2 & $42.0 \%$ & 2 \\
\hline $\begin{array}{l}\text { Maintenance and implementation level } \\
\text { of garbage disposal and collection } \\
\text { system in residential area. }\end{array}$ & $68.0 \%$ & 3 & $76.0 \%$ & 3 & $38.0 \%$ & 2 \\
\hline $\begin{array}{l}\text { The frequency of garbage collection in } \\
\text { residential area. }\end{array}$ & $64.0 \%$ & 3 & $62.0 \%$ & 3 & $76.0 \%$ & 3 \\
\hline $\begin{array}{l}\text { Maintenance and implementation level } \\
\text { of garbage disposal and collection } \\
\text { system in public area }\end{array}$ & $60.0 \%$ & 3 & $48.0 \%$ & 2 & $44.0 \%$ & 2 \\
\hline $\begin{array}{l}\text { The frequency of garbage collection in } \\
\text { public areas. }\end{array}$ & Daily & 3 & Daily & 3 & Daily & 3 \\
\hline Drains condition & $\begin{array}{l}\text { Not } \\
\text { covered }\end{array}$ & 1 & $\begin{array}{l}\text { Not } \\
\text { Covered }\end{array}$ & 1 & $\begin{array}{l}\text { Not } \\
\text { Covered }\end{array}$ & 1 \\
\hline (Total score) $/ 3$ is the highest score & $90.5 \%$ & 19 & $81.0 \%$ & 17 & $71.4 \%$ & 15 \\
\hline
\end{tabular}

\section{Public Facilities and Recreational Sector}

The public facilities highlighted in this study comprised several elements that were important to be used by children. The data from the questionnaires given to the adult and child respondents in the three neighbourhoods indicates that the satisfaction level towards the provisions of public facilities for children's use 
such as public phones, public toilets, bus stops, and children's crossings only showed a moderate rate. There were residents in Taman Sri Gombak and Seksyen 3 Petaling Jaya who claimed that the maintenance of these facilities was not up to standard. Most of the public phones were not in working conditions. It has been observed that the public phones were not specifically designed to cater for children's needs since they were built too high for children's reach. As Malone (1999) acknowledged, public phones should be built at an appropriate height for children's use and should be provided in adequate numbers in areas that were most frequented by children, especially at schools, for their safety and comfort. Public phones facility was important for children to communicate with parents when they were not under their parents' supervision. The other facility which was bus stops were not designed in such a way that provides safety to children, whereby no appropriate divider was put to separate the road from the bus stops even in an area where the roads are busy. The provision of this facility was very important especially to children who used school bus or public buses as a mode of transportation to school.

In terms of the children's crossing area, it showed that the satisfaction levels of the respondents in the three neighbourhoods were moderate and very far below the target. It has been observed in Taman Samudera and Seksyen 3 PJ that the crossing facilities were not provided in school areas, thus pose many risks and hazards to school children. In the issue of children's playgrounds, the questionnaires in the three neighbourhoods have shown a moderate level of satisfaction, especially in Taman Sri Gombak and Seksyen 3 Petaling Jaya. This was due to the inappropriate planning and designs of the playground and play equipment, which do not take into consideration the needs of children in terms of the location and play equipment provided. It has been observed in Taman Samudera and Taman Sri Gombak that there were uncovered drains near the playground that created hazards and accidents to young children.

In Seksyen 3 Petaling Jaya, the lower satisfaction level on the provision of children's playgrounds was due to the fact that their neighbourhood lacks this facility within the residential areas. From observation, there was only one children's playground available in the neighbourhood. Children were seen playing inside their house compounds and some play on streets. These scenarios may pose many risks and hazards to children thus having a negative impact on children's physical and mental growth. The children's playgrounds were not properly maintained. They are littered and unclean. Broken equipment and play things were in bad repair. In terms of street lighting, the majority of the respondents in Taman Samudera and Seksyen 3 Petaling Jaya claimed that their neighbourhoods were well lit during night time thus providing safety to their children if the children were to go out for tuition classes or to buy groceries. 
However, in Taman Sri Gombak, most of the respondents claimed that better lightings should be provided as the children usually go out at night to attend tuition class at school. Table 2 summarizes the findings of this sector for the three neighbourhoods.

\section{TABLE 2:}

Summary of Findings for Public Facilities and Recreational Aspect

\begin{tabular}{|c|c|c|c|c|c|c|}
\hline \multirow[b]{3}{*}{$\begin{array}{l}\text { Provision of public facilities used by } \\
\text { children. i) Public Phone }\end{array}$} & \multicolumn{2}{|c|}{$\begin{array}{l}\text { Taman, } \\
\text { Samudera }\end{array}$} & \multicolumn{2}{|c|}{$\begin{array}{l}\text { Taman Sri } \\
\text { Gombak }\end{array}$} & \multicolumn{2}{|c|}{$\begin{array}{l}\text { Seksyen } 3 \\
\text { Petaling Jaya }\end{array}$} \\
\hline & Findings & Score & Findings & Score & Findings & Score \\
\hline & $26.0 \%$ & 1 & $46.0 \%$ & 2 & $22.0 \%$ & 1 \\
\hline $\begin{array}{l}\text { Provision of public facilities used by } \\
\text { children. ii) Public Toilet }\end{array}$ & $12.0 \%$ & 1 & $26.0 \%$ & 1 & $20.0 \%$ & 1 \\
\hline $\begin{array}{l}\text { Provision of public facilities used by } \\
\text { children. iii) Bus Stop }\end{array}$ & $32.0 \%$ & 1 & $62.0 \%$ & 3 & $66.0 \%$ & 3 \\
\hline $\begin{array}{l}\text { Provision of crossing facilities for } \\
\text { children }\end{array}$ & $30.0 \%$ & 2 & $52.0 \%$ & 2 & $40.0 \%$ & 2 \\
\hline $\begin{array}{l}\text { Maintenance level of children's } \\
\text { crossing facility }\end{array}$ & Observation & 1 & Observation & 2 & Observation & 2 \\
\hline $\begin{array}{l}\text { Provision of appropriate and safe play } \\
\text { equipments on playgrounds in } \\
\text { residential area }\end{array}$ & $60.0 \%$ & 3 & $44.0 \%$ & 2 & $44.0 \%$ & 2 \\
\hline $\begin{array}{l}\text { Provision of appropriate playground } \\
\text { for children }\end{array}$ & $62.0 \%$ & 3 & $52.0 \%$ & 2 & $42.0 \%$ & 2 \\
\hline $\begin{array}{l}\text { *Provisions of adequate lightings } \\
\text { within the neighbourhoods }\end{array}$ & $64.0 \%$ & 3 & $26.0 \%$ & 1 & $52.0 \%$ & 2 \\
\hline Maintenance of playground & Observation & 3 & Observation & 1 & Observation & 1 \\
\hline (Total score) / (3 is the highest & $66.7 \%$ & 18 & $59.3 \%$ & 16 & $59.3 \%$ & 16 \\
\hline
\end{tabular}

* New indicators derived from the literature review

\section{Environment Sector}

The findings on this aspect showed that most of the respondents in the three neighbourhoods claimed that there were no dangerous areas such as rivers, mines and lakes in their neighbourhood areas that might pose hazards to the residents, especially the children. On the other hand, the majority of the respondents were satisfied with the noise levels in their neighbourhoods. Yet, 
there were a few respondents in Taman Samudera who claimed that their families have been bothered by a loud noise that came from a nearby construction site. The construction site, which was located beside the school area, has somehow distracted the pupils' concentration, especially during the examination period. In Taman Sri Gombak, the noise pollution could be due to the heavy traffic flow. Most of the adult and child respondents who resided in Phase 3 are affected by the loud noise that came from the nearby commercial area. In Seksyen 3 Petaling Jaya, the analysis showed that the satisfaction level towards the odour pollution was only moderate. This could be due to the garbage that has not been collected for a long time. This bad odour or smell was caused by piles of rubbish that were left unattended for a long time. This phenomenon was clearly seen through observation in some places mostly in residential areas. The residents also claimed that the bad smells have attracted wild dogs, thus creating dangers to their children. Table 3 summarizes the findings of this sector for the three neighbourhoods.

\section{TABLE 3:}

Summary of Findings for Environment Aspects

\begin{tabular}{|c|c|c|c|c|c|c|}
\hline \multirow[t]{2}{*}{ Indicators } & \multicolumn{2}{|c|}{$\begin{array}{l}\text { Taman } \\
\text { Samudera }\end{array}$} & \multicolumn{2}{|c|}{$\begin{array}{l}\text { Taman Sri } \\
\text { Gombak }\end{array}$} & \multicolumn{2}{|c|}{$\begin{array}{r}\text { Seksyen } 3 \\
\text { Petaling Jaya }\end{array}$} \\
\hline & Findines & Scote & Findings & Score & Findings & Score \\
\hline $\begin{array}{l}\text { Dangerous abandoned areas, e.g. } \\
\text { rivers, lakes, and hill slopes }\end{array}$ & $760 \%$ & 3 & $76.0 \%$ & 3 & $64.0 \%$ & 3 \\
\hline $\begin{array}{l}\text { Noise Level at children's residential } \\
\text { areas (that are close to source of loud } \\
\text { noise) }\end{array}$ & $68.0 \%$ & 3 & $42.0 \%$ & 2 & $62.0 \%$ & 3 \\
\hline $\begin{array}{l}\text { Odour Pollution Near Area Where } \\
\text { Children Live }\end{array}$ & 76.000 & 3 & $78.0 \%$ & 3 & $44.0 \%$ & 2 \\
\hline $\begin{array}{l}\text { (Total score) / (3 is the highest } \\
\text { score } \times 3 \text { indicators) } \times 100\end{array}$ & 10000 & 9 & $88,9 \%$ & 8 & $88.9 \%$ & 8 \\
\hline
\end{tabular}

\section{Sociology and Social Impact Sector}

This sector was related to the safety and security of children within the neighbourhood areas. Feedback gathered from the respondents of the three neighbourhoods showed a high satisfaction rate for this sector. Adult and child respondents in Taman Samudera and Taman Sri Gombak claimed that they felt safe to be within their neighbourhood areas including, the school areas. This could be due to the reason that there was a tight community bonding among the residents. The interaction among neighbours has created a sense of security for 
the children to play and socialize. In such environments, neighbours know each other and take care of each other's children. However, the majority of the child respondents in Seksyen 3 Petaling Jaya do not felt secure or safe within their neighbourhood areas. This could be due to the fact that Seksyen 3 was very quiet and very low in density. This was also due to the lack of social interaction among the neighbours. From the questionnaires given, a majority of the residents claimed that they were not familiar with their close neighbours because most of the residents were not permanent residents but only rent the houses there. The young children do not felt secure walking alone within their neighbourhood because they fear of being kidnapped, were afraid of harassment, theft and also fear of being raped or murdered. As a consequence, children did not access community facilities and resources or spend time in public spaces. Owing to the fear of crimes, many parents did not allow their children to move beyond the pavement outside their houses. In terms of the availability of ' $R u k u n$ Tetangga' unit in the neighbourhoods, only Seksyen 3 Petaling Jaya does have this unit. In Taman Samudera and Taman Sri Gombak, many of them claimed that they have never been in and were not aware of the existence of this unit. The establishment of this unit would be able to help the people in their objectives of fostering neighbourliness and unity. It was also to complement the job of the police in order to ensure the safety of the residents, particularly children, in the neighbourhood areas. And for children a safe environment was needed for their physical, emotional, and mental development. Table 4 summarizes the findings of this sector for the three neighbourhoods.

TABLE 4:

Summary of Findings for Sociology and Social Impact Aspects

\begin{tabular}{|c|c|c|c|c|c|c|}
\hline \multirow[t]{2}{*}{ Indicators } & \multicolumn{2}{|c|}{$\begin{array}{l}\text { Taman } \\
\text { Sanudera }\end{array}$} & \multicolumn{2}{|c|}{ Taman Sri } & \multicolumn{2}{|c|}{$\begin{array}{l}\text { Seksyen } 3 \\
\text { Petaling Jaya }\end{array}$} \\
\hline & Findings & Score & Findings & Score & Findings & Score \\
\hline $\begin{array}{l}\text { Perception on the safety level of } \\
\text { children in their neighbourhood area }\end{array}$ & $68.0 \%$ & 3 & $76.0 \%$ & 3 & $28.0 \%$ & 1 \\
\hline $\begin{array}{l}\text { Perception on the safety of children in } \\
\text { their homes and its surroundings }\end{array}$ & $82.0 \%$ & 3 & $92.0 \%$ & 3 & $94.0 \%$ & 3 \\
\hline $\begin{array}{l}\text { Perception on the safety of children in } \\
\text { their school and its surroundings }\end{array}$ & $70.0 \%$ & 3 & $79.0 \%$ & 3 & $54.0 \%$ & 2 \\
\hline $\begin{array}{l}\text { Programs for children conducted in the } \\
\text { neighbourhood }\end{array}$ & $22.0 \%$ & 1 & $21.0 \%$ & 1 & $32.0 \%$ & 2 \\
\hline $\begin{array}{l}\text { Society's involvement in children's } \\
\text { programs in the neighbourhood }\end{array}$ & $4.0 \%$ & 1 & $8.0 \%$ & 1 & $8.0 \%$ & 1 \\
\hline
\end{tabular}




\begin{tabular}{|c|c|c|c|c|c|c|}
\hline $\begin{array}{l}\text { "Perceptions of residents towards their } \\
\text { surrounding neighbours }\end{array}$ & $72.0 \%$ & 3 & $60.0 \%$ & 3 & $48.0 \%$ & 2 \\
\hline $\begin{array}{l}\text { "Availability of 'Rukun-Tetangga' } \\
\text { within the Neighbourhood }\end{array}$ & $46.0 \%$ & 2 & $56.0 \%$ & 2 & $64.0 \%$ & 3 \\
\hline $\begin{array}{r}\text { (Total score) } /(3 \text { is the highest } \\
\text { score } x 7 \text { indicators) } 100\end{array}$ & $76.2 \%$ & 16 & $762 \%$ & 16 & $66.7 \%$ & 14 \\
\hline
\end{tabular}

* New indicators derived from the literature review

\section{Transportation and Accessibility Sector}

This sector was related to the safety of the children. It has been found in three study areas that children's walking and cycling to school showed a low percentage. This can be due to the longer distances to school and also due to the withdrawal of parental permission for children to be on the streets alone. Apart from that it could also be due to the highly car-based lifestyles of the residents in these neighbourhoods and low quality of public transport services. In Taman Samudera, the low percentage of students walking and cycling to school was due to the fact that most of the parents were concerned about their children's safety because their neighbourhood areas have not been provided with safe and connected pedestrian and bicycle routes. Children without parental supervision were seen walking dangerously and recklessly on the street. Table 5 summarizes the findings of this sector for the three neighbourhoods.

TABLE 5:

Summary of Findings for Transportation and Accessibility Aspects

\begin{tabular}{|c|c|c|c|c|c|c|}
\hline \multirow[t]{2}{*}{ Indicators } & \multicolumn{2}{|c|}{$\begin{array}{l}\text { Taman } \\
\text { Samudera }\end{array}$} & \multicolumn{2}{|c|}{ Taman Sri } & \multicolumn{2}{|c|}{$\begin{array}{c}\text { Seksyen } 3 \\
\text { Petaling Jaya }\end{array}$} \\
\hline & Findings & Score & Findings & Score & Findings & Score \\
\hline $\begin{array}{l}\text { Percentage of student walking to school } \\
\text { / Number of school students }\end{array}$ & $26.0 \%$ & 1 & $28.0 \%$ & 1 & $16.0 \%$ & 1 \\
\hline $\begin{array}{l}\text { Percentage of student cycling to school } \\
\text { / Number of school students }\end{array}$ & $12.0 \%$ & I & $10.0 \%$ & 1 & $10.0 \%$ & 1 \\
\hline $\begin{array}{l}\text { Percentage of student taking school } \\
\text { buses/ Number of school students }\end{array}$ & $34.0 \%$ & 2 & $22.0 \%$ & 1 & $32.0 \%$ & 2 \\
\hline $\begin{array}{l}\text { Percentage of student using private } \\
\text { transportation/ Number of school } \\
\text { students }\end{array}$ & $24.0 \%$ & 1 & $24.0 \%$ & 1 & $30.0 \%$ & 2 \\
\hline $\begin{array}{l}\text { Percentage of student using public } \\
\text { buses / Number of school students }\end{array}$ & 4.05 & 1 & $14.0 \%$ & 1 & $12.0 \%$ & 1 \\
\hline
\end{tabular}




\begin{tabular}{|c|c|c|c|c|c|c|}
\hline $\begin{array}{l}\text { Provision of pedestrian ways and } \\
\text { cycling lanes at school area }\end{array}$ & Observation & 1 & Observation & 1 & Observation & 2 \\
\hline $\begin{array}{l}\text { Provision of crossing areas/lanes at } \\
\text { school }\end{array}$ & Observation & 1 & Observation & 2 & Observation & 1 \\
\hline $\begin{array}{l}\text { Provision of pedestrian ways and } \\
\text { bicycle lanes to connect public ways }\end{array}$ & Observation & 1 & Observation & 1 & Observation & 2 \\
\hline $\begin{array}{l}\text { Maintenance of pedestrian ways and } \\
\text { cycling lanes in school areas }\end{array}$ & Observation & 1 & Observation & 1 & Observation & 1 \\
\hline $\begin{array}{l}\text { Provision of signage along the road in } \\
\text { neighbourhood areas }\end{array}$ & $60.0 \%$ & 3 & $75.0 \%$ & 3 & $70.0 \%$ & 3 \\
\hline $\begin{array}{l}\text { (Total score) / ( } 3 \text { is the highest } \\
\text { score } \times 10 \text { indicators) } 100\end{array}$ & $43.3 \%$ & 13 & $43.3 \%$ & 13 & $53.3 \%$ & 16 \\
\hline
\end{tabular}

\section{ISSUES AND PROBLEMS IDENTIFIED FROM THE STUDY}

From the findings and analyses that have been done, it has been found that none of the neighbourhoods have achieved the target of 'child-friendly environment'. The study areas were facing a number of problems and basically the problems were similar for each neighbourhood. Among the problems were those mostly related to the inadequacy of the provision of public facilities that meet the children's needs. Among the facilities were the provision of children's crossing areas, the public transportation's stops, public toilets, and public phones. On top of that, these facilities were not specifically designed to cater for children's needs. The public phones were built too high for children to reach. Public phones, however, should be built at an appropriate height for children's use and provided in areas frequented by children especially at schools for their safety and comfort. In terms of the provisions of public toilets, which were located mostly in public areas, they were still not up to standard and were not suitable for children's use. From observations, it has been found that the main issue of the public toilets in these three neighbourhoods was the low level of their cleanliness. Another issue was the issue of uncovered drains. It has been found that most of the drains within the neighbourhoods were not well covered and properly maintained, thus creating risks and hazards to young children.

Among other major problems that have been identified was the level of cleanliness especially in the public areas. Cleanliness was one of the most important aspects in determining the health and well-being of the children. In their everyday life, children regularly move in and between the spaces of the home, street and neighbourhood thus, having clean neighbourhoods is important 
to ensure children's safety and good health. The declining number of children walking and cycling to school in these neighbourhoods has been well attested through the analysis that has been done. This was due to the lack of the safety features such as safe and connected pedestrian and bicycle lanes provided within the neighbourhoods' area. Many studies show that the propensity of the children to walk and cycle was significantly affected by how safe, enjoyable, convenient, and pleasurable the experience of walking and cycling was. Furthermore, the declining number of children walking and cycling to school was also due to longer distances to school and also due to the withdrawal of parental permission for children to be on the streets alone. Apart from that, the provision of children's crossing areas was also one of the major problems faced by these neighbourhoods. The provision of this facility was still inadequate especially in school areas and other areas frequented by children. As Bartlett (2002) acknowledges, school children, particularly young children, were more exposed to road accidents, as they cannot measure how fast the car was moving.

Apart from that the issues identified were the safety and security of residents within their neighbourhood areas. There were a number of young children who expressed their fear of harassment or abuse and as a consequence did not access community facilities and resources or spend time in public space. Parents were more likely to prioritise enhanced security and traffic safety. Owing to the fear of crimes, many parents did not allow their children to move beyond the pavement outside their house. This issue could be related to the perceptions of the residents towards their own neighbours. The sense of community must be enhanced in order to create a child-friendly environment for the children. The inadequacy of the provision of street lightings was also one of the problems identified in this study. Provision of better lighting was important in order to ensure the safety of the children especially during night time when children are likely gone out for night classes or tuition. Societal awareness of children's programme is still found lacking in these three neighbourhoods. This issue should be well addressed in order to create a child-friendly environment for children's mental, spiritual, and physical development. The absence of the 'Rukun Tetangga' unit was also one of the issues faced. On the whole, from the issues and problems identified in this study, it can be concluded that the physical environment of a neighbourhood affects health and well-being both directly through the quality of housing and public space, and indirectly, through the impact on behaviour and the sense of community. 


\section{RECOMMENDATIONS}

In order to create a child-friendly environment for children, especially for those aged 7 to 17 years old, several recommendations with regard to neighbourhoods were outlined. Recommendations on the neighbourhoods will be focused on three important aspects which are;

i) Residential areas;

ii) Open spaces and recreational parks; and

iii) Neighbourhood movement planning

\section{Residential Areas}

The residential area was a basis for community development. As children are part of the community, having well-planned, safe, and healthy residential areas will enhance the community transcendences. The residential area is the place children encounter each day. They need a safe housing environment in which to live, play, run errands, thus helping to develop their physical and mental growth. Since the three neighbourhoods did not achieve the target of the child-friendly environment, the following recommendations are, therefore, made;

\section{i) Maintaining Good Levels of Cleanliness}

Cleanliness was the most important aspect in determining the health of the residents, especially children. Although many of the residents of the study areas claimed that the frequency of the garbage collection system in the housing area is 3 times a week, from the observation done the cleanliness of the neighbourhoods was still at a lower level. Apart from relying on the local authorities, the residents should have the initiative to keep their neighbourhoods clean. Weekly voluntary work or 'Gotongroyong' programmes could be one of the methods that can be carried out among the residents in order to keep their neighbourhoods clean and, thus help in a creating child-friendly environment. A well-managed garbage collection, handling and disposal facility and well-maintained and covered drains were important to help maintain children's health and safety. The efficient removal of garbage was important not only to prevent the breeding of certain disease vectors, but also to ensure that the surroundings of the neighbourhoods were safe and inviting for children's play. 
ii) Improvement of Drains

Uncovered and some broken drains will compromises the safety of children who usually to play near the area. Their safety was most concerned especially during the rainy season when the drains will be filled with water. In this case, the local authorities should take action to solve this problem by upgrading the present condition of the drains. The top parts of drains should be well covered to avoid accidents especially among children. Apart from that, the quality of the material used for the drain covers should be observed.

iii) Improvement of Signboards

The design of signs and signboards must consider children's ability to read from afar. They should be clear enough to enable children to read and find their destinations easily. The provisions of signs must be enhanced in terms of their quantity as well as their quality. Children easily get lost even within their own housing areas, thus adequate signs must be provided. The authorities must also provide better materials for the signboards.

iv) Facilities For and Used By Children

Children's crossings are hardly to be seen in the three case study areas. The provision of children's crossings such as zebra crossings and overhead bridges are so important, especially in school areas, in order to ensure the safety of the school children. Overhead bridges should be provided in areas with heavy traffic flow. Children should not be allowed to cross roads without using these crossings. In school areas, the provision of zebra crossings is a must and the school should be able to provide 'lollipop man' to help children cross the road safe and sound.

v) Better Lighting

The provision of adequate lighting is important to ensure the safety and security of the children especially those who tend to go out at night for tuition class, to a friend's house, to buy groceries, and so forth. The inadequacy of this facility may compromise the safety of children especially, females. The females are most likely to be exposed to heinous crimes such as rape and murder.

vi) 'Rukun Tetangga' Unit

Blending 'Rukun Tetangga' (RT) with the Neighbourhood Watch (NW) will be akin to killing two birds with one stone to bring more benefits to residents, especially to children. 'Rukun Tetangga' 
focuses on unity and fostering relationships among the people in the neighbourhood. The presence of the 'Rukun Tetangga' would be able to help the people in their objectives of fostering neighbourliness and unity and thus have a positive impact on children's growth and well-being.

\section{Open Space and Recreational Park}

According to De Chiara, J., Julius, P., and Zelnik, M. (1995), every residential neighbourhood requires a range of facilities for both children and adults that are easily accessible to the living units. Open spaces are not only provided for specific recreational opportunities but also encourage healthy lifestyles and the potential for social contact. Generally, the provision of open space for children's recreational purposes in housing areas has a positive impact in helping children's development process. Thus it is crucial to provide a proper, comfortable and safe play area for children to play in. From the analysis done, it can be concluded that most of the children's playgrounds in the three neighbourhoods are still not up to the standard and should be improved in order to create a safe environment for children. Regarding to this, few recommendations has been made:

i) Suitable Location of Children's Playground

Local residents, particularly children and teenagers, should have the realistic option of walking or cycling to an appropriate range of open space facilities, and be able to walk between spaces on the green network. Apart from that, children's playgrounds should be located as close as possible because they are most frequently and intensively used by children who live in the immediate vicinity. The most appropriate distance for a children's playground should be within 5 minutes walk or $400 \mathrm{~m}$ actual distance of every home. The $400 \mathrm{~m}$ actual distance is based on general research showing that most young children travel less than that to play. The safety of the route is also important. Most young children are not allowed to cross main roads thus; the location of this playground must take these limits into account. Apart from that, the entire area should be enclosed and screened off from adjacent areas to prevent children from wandering around and to provide noise insulation for nearby living units.

\section{ii) Variety of Spaces for Various Activities}

Open space for children's recreational purposes should be designed in such a way that children could fully utilise and manipulate the 
area and it serves the needs of both boys and girls of different ages. This is very important in developing their physical and mental growth. Variety of spaces in children's playground includes;

- Apparatus area for swings, slides, jungle gyms, and other equipment;

- Courts and fields for games such as basketball, softball, soccer, tennis, handball and volleyball;

- Open area for running, jumping, and informal play;

- Area for quite games such as checkers, chess, crafts, and hobbies;

- A shaded area for quite activities;

- Picnic areas; and

- Sitting area for parents to look after their children and for children to rest.

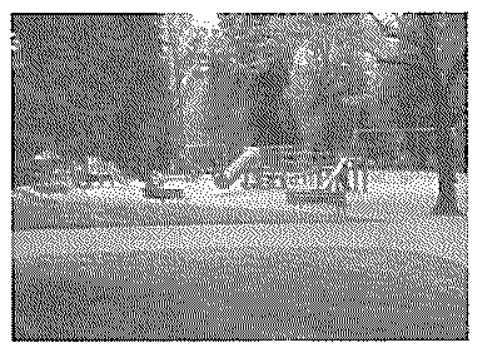

Variety of spaces at children's playgrounds

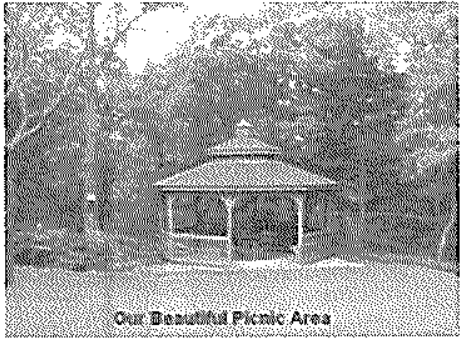

Provision of sitting or picnic area

iii) Safe and Suitable Play Equipment

Children are sometimes exposed to accidents when playing in the playgrounds. Children's playground should be equipped with high quality of play equipments in order to ensure the safety of the children. It has been identified through observation that most of the playgrounds within the case study areas are still neglect the safety element for a safe children's playground. Thus few suggestions have been proposed:

- Broken equipments should be removed to avoid any fall off or other dangerous incidents from happening;

- Play equipment must be provided according to the different ages of children; 
- Play equipment should be designed in structurally stable conditions. They must be arranged with appropriate distance from each other to avoid accident among children.

- Play equipment must be at least in two types of colour in order to attract children and increase their safety level;

- The provision of guardrail to ensure children's safety;

- Slides should not be more than 30 degree gradient to ensure that children's body can move in controllable speed; and

- "Fall Zone" area that surrounded the play equipments should be expanded to $1.2 \mathrm{~m}$ to ensure children's safety.

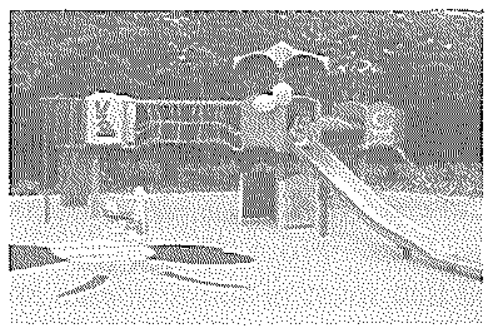

Fall zone surrounding the play equipments to ensure the children's safety

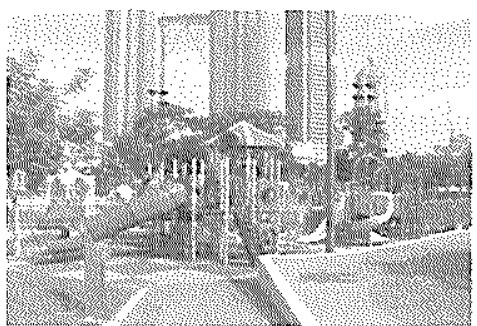

Stable play equipments to avoid any unintentionally accidents on children

iv) Maintain Good Level of Cleanliness at Children's Playgrounds

Children's playgrounds and recreational parks should be well maintained in terms of their cleanliness. They should be clean enough in order to create a healthy environment for the users particularly the children. To achieve a high level of cleanliness, the authorities should give real teeth when assigning the responsible staff or workers to always ensure the cleanliness of the open spaces and parks. There should be consistent dates for inspection, proper schedule on the types of maintenance programmes and person in charge. The garbage collection should be done at least 3 times a week in order to maintain the cleanliness level of the open space for children's recreational use. Apart from that, the residents from these three neighbourhoods can take initiatives by organizing weekly 'voluntary community work' for their neighbourhoods. This programme could help in fostering community development among the residents. Furthermore, high levels of cleanliness can also be achieved through the appropriate provision of garbage disposal within the playgrounds and parks. Signboards showing phrases like 'Keep This Area Clean' should be provided in order to create awareness among users, particularly the children. 
v) Appropriate Landscape Design

The landscape design of the open spaces must be taken into account in order to create an attractive, comfortable and conducive environment for children to enjoy. Good design of landscape elements will provide a better visual impact for the surrounding environment. However, the purpose of having trees is not only for the aesthetical value, but to provide shady areas for play activities during the daytime.

\section{Neighbourhood Movement Planning}

Network movement is one of the main components in a settlement as it connects various activities within the settlement itself. Vehicular traffic has to be sufficiently tamed so as to pose little threat in terms of accidents especially to children. Indeed, providing safe routes and movement for children is increasingly important in order to develop children's ability to be independent as well as to enhance children's lives. From the analysis of the three neighbourhoods, it can be concluded that most of the residents are not satisfied with the safety of their children in terms of the network system provided in their neighbourhood areas. Below are few recommendations that have been proposed based on the issues and problems which arise;

\section{i) Safe and Connected Pedestrian Route}

Pedestrian activity is the livehood of the neighbourhood. Enabling easy and free pedestrian movement is, therefore, a very high priority. To ensure the safety of children when walking in the neighbourhoods, a numbers of measures should be taken into account:

- Pedestrian routes must be continuous, connected and as direct as possible in order to reduce distance to be walked and increase the pedestrian catchments of facilities;

- Green spaces should be linked to the network to allow for round walks, and where 'green routes' to major centers of activities such as children's playground;

- Pedestrians ways should be provided with good permeability whereby choices of routes filtering through an area allowing pedestrian especially the children to go which way they wanted to go;

- It is vital to provide easy, direct access to public transport facilities for the convenience of the children; 
- Pedestrian routes should avoid steep hills, unnecessary barriers, steps or kerbs that might inhibit less agile people such as children in particular;

- Routes should be well lit and feel safe, without dark corners or featureless, unconnected sections that might be intimidating to children particularly;

- Pedestrian routes should be linked by convenient and safe crossings, with minimum diversion to meet children's need;

- Apply the concept of 'Safe Routes to School' at every neighbourhood in the country; and

- Provision of water cooler facility to encourage the children to walk.
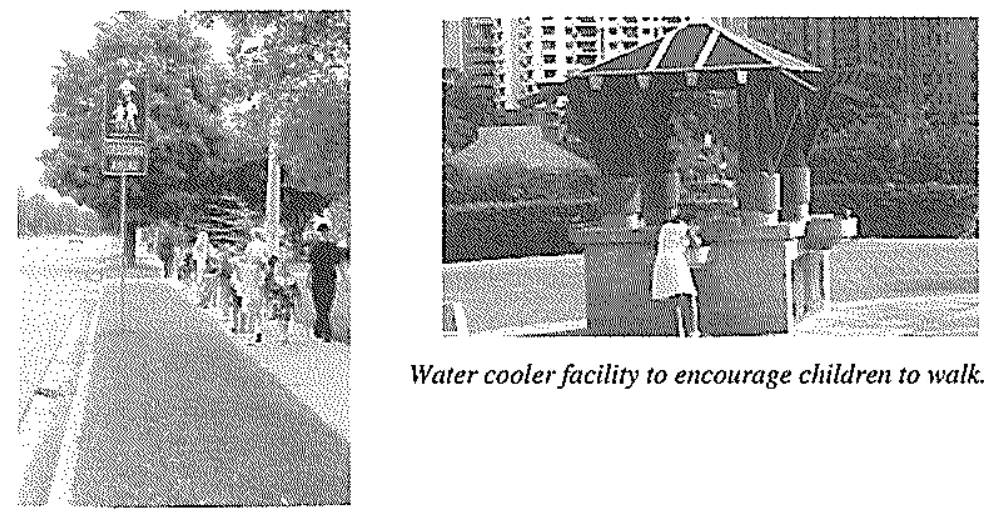

Water cooler facility to encourage children to walk.

Pedestrian route that linked by safe crossings for children's safety

ii) Safe and Connected Bicycle Lanes

Ordinary streets throughout the neighbourhood should be managed for bicycle use, linking directly with the surrounding areas. This requires that vehicle traffic be 'calmed' in order to ensure the safety of users, especially children. To improve the present condition of the bicycle lanes in the three neighbourhoods, a few suggestions have been outlined:

- Separate lanes or paths should be provided especially in area with heavy or fast-moving traffic is unavoidable, in order to reduce accidents that likely to happen on children;

- Main bicycle routes should be as continues as possible, with few stops;

- Cycling paths should ensure easy gradients (normal maximum 6 percent), a smooth surface and protected from fumes; 
- Cycling paths can share surfaces with pedestrians on segregated routes in order to ensure the safety of the children;

\section{iii) Safe Crossings Areas for Children}

The provision of children's crossings is very important to determine the safety of the children especially in school areas. Children's crossings must be well maintained in order to ensure the safety of the children. It should be clear enough to be seen by children for their safety and comfort. Without proper children's crossings, especially in school areas, it may create hazards and traffic accidents to children. Indicates the example of a wellmaintained children's crossing provided in a school area.

\section{TABLE 6:}

Summary of Issues and Problems, and Recommendations

\begin{tabular}{|c|c|}
\hline ISSUES AND PROBLEMS & RECOMNENDATIONS \\
\hline Safety of Children & $\begin{array}{l}\text { Provision of safe and comfortable pedestrian walkways } \\
\text { - Provision of safe and connected bicycle lanes/routes } \\
\text { Provision of children's crossings especially in school } \\
\text { areas } \\
\text { - } \\
\text { - Planning for suitable locations of children's playground } \\
\text { - Provision of safe and suitable play cquipment at } \\
\text { children's playeround } \\
\text { Appropriate locations of bus stops that are secure from } \\
\text { traffic to avoid accidents }\end{array}$ \\
\hline Security and Supervision of Children & $\begin{array}{l}\text { - Provision of adequate lighting in neighbouthood areas } \\
\text { - The anailability of 'Rukun Tetangga' unit in the } \\
\text { neighbourhoods }\end{array}$ \\
\hline Heath of Children & $\begin{array}{l}\text { - Maintaining the cleanliness level of the neighbourhoods } \\
\text { and public areas : } \\
\text { Maintain the cleanliness of the children's playground }\end{array}$ \\
\hline Mental and Physical enhancement & $\begin{array}{l}\text { Provision of suitable and appropriate height of public } \\
\text { phones, and other facilities for and ised by chitdren } \\
\text { - Clean and comfortable public toilets } \\
\text { - Appropriate landscape design at children's playground }\end{array}$ \\
\hline . & $\begin{array}{l}\text { - Provision of appropriate, suitable children's playground } \\
\text { Various spaces for various activities in children's } \\
\text { playground } \\
\text { Programmes organised for children within the } \\
\text { neighbourhoods }\end{array}$ \\
\hline
\end{tabular}




\section{ACKNOWLEDGEMENT}

This study was funded under the IIUM research grant no. IIUM/504/RES/G/14/3/03/C 47. The first study was granted as a consultancy work to IIUM Consultancies and Entrepreneurship Sdn. Bhd. (IEC Sdn. Bhd.) by the Federal Department of Town and Country Planning, Peninsular Malaysia in 2002. Modification and adjustment to the original indicators, Child-MesraNet System and its model were done in this research work. The authors would like to thank IIUM Research Centre, Kulliyyah of Architecture and Environmental Design, IIUM and IEC Sdn. Bhd. on their supports and funding.

\section{REFERENCES}

Badaruddin Mohamed. 2002. Planning for the Children of the Future: The Case of Malaysia. http://www.araburban.org/childcity/Papers/English/Badaruddin.pdf.

Bartlett, S. 2002. Children's Experience of the Physical Environment in Poor Urban Settlements and The Implications for Policy, Planning and Practice, Environment and Urbanization. Vol 11, No.2, 63-73.

Bartlett, S., Hart R., Satterhwaite, D., De La Barra, X., Missair, A. 1999. Cities for Children: Children's Rights, Poverty and Urban Management. London: Earthscan.

Barton, H., Grant, M., Guise, R. 2003. Shaping Neighbourhoods: A Guide for Health, Sustainability and Vitality. New York: Spon Press.

Charlesworth, R. 2002. Understanding Child Development ( $5^{\text {th }}$ Edition). New York: Delmar/Thomson Learning.

Chawla, L. (Ed.) 2002. Growing Up in an Urbanizing World. London: Earthscan.

Christensen, P., O'Brien, M. (Eds.) 2003. Children in the City: Home, neighbourhood and community. New York: Routledge Falmer.

De Chiara, J., Julius, P., and Zelnik, M. 1995. Time-Saver Standards for Housing And Residential Development. New York: McGraw-Hill, Inc.

Malone, K. 1999. Growing Up in Cities 'As a Model of Participatory Planning and 'Place-Making' With Young People. Youth Studies Australia. June 1999 , Vol.18 No.2

http://www.acys.utas.edu.au/nycs/ycys/articles/ysa_pdfs/ysa-v18n2pp1723.pdf

Ministry of Health Malaysia. 2000. Annual Report. Kuala Lumpur

Norasiah Yahya. 1998. The Comfort of Children Surroundings from the Perspective of Urban Planner. Jurnal Kebajikan. Vol. 20. No. 2. December, 1998. 
Town and Country Planning Act 1976 (Act 172). Kuala Lumpur: Town and Country Planning Department Peninsular Malaysia

UNICEF 1998. State of the World's Children. New York: UNICEF. 